\title{
Enucleation in Asian Indian patients: a histopathological review of 2009 cases
}

\author{
Swathi Kaliki ${ }^{1}$ Sai Divya Jajapuram ${ }^{1} \cdot$ Kavya Madhuri Bejjanki $^{1} \cdot$ George Ramappa $^{1} \cdot$ Ashik Mohamed $^{2}$. \\ Dilip K Mishra ${ }^{3}$
}

Received: 21 June 2018 / Accepted: 28 June 2018 / Published online: 12 October 2018

(c) The Royal College of Ophthalmologists 2018

\begin{abstract}
Objective To review the indications of enucleation in Asian Indian patients and study the trend over the 22-year period. Methods Retrospective study of 2009 patients who underwent enucleation.

Results The mean age at presentation of patients who underwent enucleation was 155 months The histopathology diagnosis included a benign tumor $(n=22,1 \%)$, malignant tumor $(n=1472,73 \%)$, acute trauma $(n=93,5 \%)$, retinal vascular disease $(n=50,3 \%)$, inflammatory/infective pathology $(n=33,2 \%)$, or other miscellaneous/non-specific diagnosis $(n=460,23 \%)$. There was a good correlation between the clinical and histopathology diagnoses at $96 \%$. The most common indication for enucleation in young patients ( $\leq 20$ years) was retinoblastoma $(n=1257,82 \% ; p<0.001)$, atrophic bulbi or phthisis bulbi $(n=163,39 \% ; p<0.001)$ in middle-age adults, and uveal melanoma $(n=25,42 \% ; p<0.001)$ in older adults. Over the years, there was a decreasing trend of enucleations for atrophic bulbi/phthisis bulbi/painful blind eye (33\% from the years 1996 through 2000 to $7 \%$ from 2010 to $2018 ; p<0.001)$ and acute trauma (3\% from the years 1996 through 2000 to $<1 \%$ from 2010 to 2018; $p<0.001$ ) and an increasing trend for intraocular tumors including retinoblastoma (56\% from the years 1996 through 2000 to $73 \%$ from 2010 to $2018 ; p=0.01$ ) and uveal melanoma (3\% from the years 1996 through 2000 to $11 \%$ from 2010 to $2018 ; p<0.006$ ).

Conclusion In Asian Indian population, malignant tumors remain the most common indication for enucleation in young and older patients, while desire for better cosmesis with customized ocular prosthesis is the main indication for enucleation in middle-age adults.
\end{abstract}

\section{Introduction}

Though there are various globe-salvaging medical and surgical treatment modalities, enucleation is still the treatment of choice for end-stage ocular disease. However, the indications and incidence of enucleation may vary in each country. Based on population-based surveys, the annual incidence of enucleation is gradually

Swathi Kaliki

kalikiswathi@yahoo.com

1 Operation Eyesight Universal Institute for Eye Cancer, Hyderabad, India

2 Ophthalmic Biophysics Laboratory L V Prasad Eye Institute, Hyderabad, India

3 Ophthalmic Pathology Laboratory L V Prasad Eye Institute, Hyderabad, India decreasing. In a study from United States of America (US), it was noted that the incidence of enucleation decreased from 6.82 per 100,000 population in 1956 through 1966 , to 4.64 per 100,000 population in 1967 through 1977 , to 2.80 per 100,000 population in 1978 through 1988 [1]. In studies from Iceland, it was noted that the incidence of enucleation in 1964 through 1992 was 2.66 per 100,000 which decreased to 1.48 per 100,000 during the years 1992 to 2004 [2, 3].

Over the years, there is a changing pattern of diseases leading to enucleation. A large study of 3264 globes over a six-decade period revealed that glaucoma was the most common cause of enucleation in 1950's and 1960's, acute trauma in 1970's and 1980's, and intraocular malignant tumors in 1990's and 2000's [4]. In this study, we evaluated the indications of enucleation and the changing pattern of diseases leading to enucleation in Asian Indian population over a 22-year period. 
Table 1 Enucleation in Asian Indian population:

demographics

\begin{tabular}{llllll}
\hline Feature & $\begin{array}{l}\text { All cases } \\
n=2009 n \\
(\%)\end{array}$ & $\begin{array}{l}\text { Young age }(\leq 20 \\
\text { years } n=1531 n \\
(\%)\end{array}$ & $\begin{array}{l}\text { Middle age }(>20 \text { to } \\
60 \text { years }) n=418 n \\
(\%)\end{array}$ & $\begin{array}{l}\text { Older age }(>60 \\
\text { years }) n=60 n \\
(\%)\end{array}$ & $p$-value \\
\hline $\begin{array}{l}\text { Age (months) Mean } \\
\text { (median, range) }\end{array}$ & $\begin{array}{l}155(48, \\
\text { Gender }\end{array}$ & $47(36,0.3-240)$ & $452(444,241-720)$ & $\begin{array}{l}84(840, \\
834-1020)\end{array}$ & $<0.001$ \\
$\quad \begin{array}{l}\text { Male } \\
\text { Female }\end{array}$ & $1191(59)$ & $887(58)$ & $267(64)$ & $37(62)$ & 0.54 \\
$\begin{array}{l}\text { Enucleation } \\
\quad \text { Primary }\end{array}$ & $818(41)$ & $644(42)$ & $151(36)$ & $23(38)$ & 0.34 \\
$\quad$ Secondary & $473(24)$ & $457(30)$ & $11(3)$ & $55(92)$ & $<0.001$ \\
\hline
\end{tabular}

\section{Methods}

Institutional review board approval was obtained for the study. Histopathological diagnoses of all cases performed in Ophthalmic Pathology Laboratory at LV Prasad Eye Institute, Hyderabad, India from January 1996 to March 2018 were reviewed. The patients who had undergone enucleation were included in this study. Those with inadequate data were excluded from the study.

The data extracted from the medical records included age at presentation, gender, and clinical diagnosis. Final histopathology diagnosis of each case was recorded from the histopathology records. The correlation between clinical and histopathology diagnoses was also reviewed.

The cases were classified and analyzed further based on age at presentation. Young age was defined as $\leq 20$ years, middle age as $>20$ to 60 years, older adults as age $>60$ years. Primary enucleation was defined as enucleation done as a primary treatment for the ocular pathology and secondary enucleation, when enucleation was done when other conservative measures failed. The cases were further classified and analyzed further based on the decade at presentation.

The data were also analyzed based on the year of enucleation. The cases were divided into 5 groups, those in years 1996 to 2000,2001 to 2005,2006 to 2010,2011 to 2015, and 2016 to 2018.

\section{Statistical analysis}

The statistical analysis was performed using the software STATA v11.0 (StataCorp, College Station, Texas, USA). The comparison of categorical data was performed using Chi-square test. The continuous data were compared using Kruskal-Wallis test. A $p$-value of $<0.05$ was considered statistically significant. For post-hoc analysis, categorical and continuous data were compared using Chi-square and Mann-Whitney tests, respectively. Appropriate Bonferroni corrections were applied when performing pair-wise comparisons of three (age-wise) or five (year-wise) groups.

\section{Results}

Of $>20,000$ cases reviewed in Ophthalmic Pathology Laboratory, 2009 (<10\%) enucleated cases were included in the study. Of these patients, 1531 (76\%) were young, 436 $(22 \%)$ were middle-age adults, and $60(3 \%)$ were older adults. The mean age at enucleation was 155 months (median, 48 months; range, $<1$ to 1020 months) (Table 1).

Overall, the most common indication for enucleation was retinoblastoma $(n=1262,63 \%)$. There was a good correlation between the clinical and histopathology diagnoses at $96 \%$. Primary enucleation $(76 \%)$ was more common than secondary enucleation (24\%). Primary enucleation was more common in middle-aged (97\%) and older adults (92\%) compared to young patients $(70 \%)(p<0.001)$. Secondary enucleation was more common in the young patients $(30 \%)$ compared to middle-aged (3\%) and older adults $(8 \%)(p<$ 0.001 ). Retinal tumors were predominant in the young patients $(86 \%$ in young, $2 \%$ in middle-age, and $0 \%$ in older adults; $p<0.001)$; uveal tumors in the middle-aged and older adults ( $<1 \%$ in young, $38 \%$ in middle-age, and $55 \%$ in older adults; $p<0.001$ ); and tumors arising from the conjunctiva or cornea were more frequent in the older adults $(<1 \%$ in young, $3 \%$ in middle-age, and $17 \%$ in older adults; $p<$ 0.001 ). Based on etiology, malignant tumor (predominantly retinoblastoma; $p<0.001$ ), and retinal vascular pathology (Coats disease; $p=0.002$ ) were the common etiologies in the young patients; acute trauma $(p<0.001)$ and sequelae of prior trauma and infection $(p<0.001)$ were common in the middle-aged adults, and acute inflammation or infection (endophthalmitis and panophthalmitis; $p=0.009$ ), benign tumors (choroidal hemangioma, $p=0.009$; choroidal melanocytoma, $p<0.001$; and choroidal osteoma, $p<0.001$ ); and malignant tumors (choroidal metastasis, $p<0.001$; ocular surface squamous neoplasia, $p<0.001$; and uveal melanoma, 
Table 2 Enucleation in Asian Indian population: diagnosis

\begin{tabular}{|c|c|c|c|c|c|}
\hline Feature & $\begin{array}{l}\text { All cases } \\
n=2009 \\
n(\%)\end{array}$ & $\begin{array}{l}\text { Young age } \\
(\leq 20 \text { years }) \\
n=1531 n(\%)\end{array}$ & $\begin{array}{l}\text { Middle age (>20 } \\
\text { to } 60 \text { years) } \\
n=418 n(\%)\end{array}$ & $\begin{array}{l}\text { Older age } \\
\text { (>60 years) } \\
n=60 n(\%)\end{array}$ & $p$-value \\
\hline \multicolumn{6}{|c|}{ Clinical diagnosis correlating with histopathology diagnosis } \\
\hline Yes & $1937(96)$ & $1479(97)$ & $403(96)$ & $55(92)$ & 0.96 \\
\hline No & $72(4)$ & $52(3)$ & $15(4)$ & $5(8)$ & 0.16 \\
\hline \multicolumn{6}{|l|}{ Tissue of origin of the pathology } \\
\hline Conjunctiva/cornea & $26(1)$ & $3(<1)$ & $13(3)$ & $10(17)$ & $<0.001$ \\
\hline Vitreous & $2(<1)$ & $2(<1)$ & $0(0)$ & $0(0)$ & 0.73 \\
\hline Ciliary body/choroid & $204(10)$ & $13(<1)$ & $158(38)$ & $33(55)$ & $<0.001$ \\
\hline Retina & $1316(66)$ & $1309(86)$ & $7(2)$ & $0(0)$ & $<0.001$ \\
\hline Optic nerve & $1(<1)$ & $0(0)$ & $1(<1)$ & $0(0)$ & 0.15 \\
\hline Non-specific & $460(23)$ & $204(13)$ & $239(57)$ & $17(28)$ & $<0.001$ \\
\hline \multicolumn{6}{|l|}{ Etiology } \\
\hline Congenital anomalies & $7(<1)$ & $7(<1)$ & $0(0)$ & $0(0)$ & 0.34 \\
\hline Retinal vascular pathology & $50(3)$ & $49(3)$ & $1(<1)$ & $0(0)$ & 0.002 \\
\hline Acute Inflammation/infection & $33(2)$ & $21(1)$ & $8(2)$ & $4(7)$ & 0.009 \\
\hline Acute trauma & $93(5)$ & $24(2)$ & $68(16)$ & $1(2)$ & $<0.001$ \\
\hline $\begin{array}{l}\text { Sequelae of prior trauma or } \\
\text { infection }\end{array}$ & $332(17)$ & $157(10)$ & $163(39)$ & $12(20)$ & $<0.001$ \\
\hline Benign tumor & $22(1)$ & $7(<1)$ & $10(2)$ & $5(8)$ & $<0.001$ \\
\hline Malignant tumor & $1472(73)$ & $1266(83)$ & $168(40)$ & $38(63)$ & $<0.001$ \\
\hline \multicolumn{6}{|l|}{ Histopathology diagnosis } \\
\hline \multicolumn{6}{|l|}{ Congenital anomalies } \\
\hline Clinical anophthalmos & $1(<1)$ & $1(<1)$ & $0(0)$ & $0(0)$ & 0.86 \\
\hline Noorie's disease & $1(<1)$ & $1(<1)$ & $0(0)$ & $0(0)$ & 0.86 \\
\hline $\begin{array}{l}\text { Primary hyperplastic } \\
\text { primary vitreous }\end{array}$ & $2(<1)$ & $2(<1)$ & $0(0)$ & $0(0)$ & 0.73 \\
\hline Retinal dysplasia & $3(<1)$ & $3(<1)$ & $0(0)$ & $0(0)$ & 0.63 \\
\hline \multicolumn{6}{|l|}{ Retinal vascular pathology } \\
\hline Coats disease & $50(3)$ & $49(3)$ & $1(<1)$ & $0(0)$ & 0.002 \\
\hline \multicolumn{6}{|l|}{ Acute Inflammation/infection } \\
\hline $\begin{array}{c}\text { Intraocular cysticercosis/ } \\
\text { toxocariasis/parasitic granuloma }\end{array}$ & $7(<1)$ & $7(<1)$ & $0(0)$ & $0(0)$ & 0.34 \\
\hline $\begin{array}{l}\text { Endophthalmitis/ } \\
\text { panophthalmitis }\end{array}$ & $20(<1)$ & $9(<1)$ & $8(2)$ & $3(5)$ & $<0.001$ \\
\hline $\begin{array}{l}\text { Necrotizing granulomatous } \\
\text { uveitis }\end{array}$ & $6(<1)$ & $5(<1)$ & $0(0)$ & $1(2)$ & 0.08 \\
\hline Acute trauma & $93(5)$ & $24(2)$ & $68(16)$ & $1(2)$ & $<0.001$ \\
\hline \multicolumn{6}{|c|}{ Sequelae of prior trauma or infection } \\
\hline $\begin{array}{l}\text { Phthisis bulbi/atrophic bulbi/ } \\
\text { Painful blind eye }\end{array}$ & $325(16)$ & $150(10)$ & $163(39)$ & $12(20)$ & $<0.001$ \\
\hline \multicolumn{6}{|l|}{ Benign tumor } \\
\hline $\begin{array}{l}\text { Ciliary body } \\
\text { medulloepithelioma }\end{array}$ & $5(<1)$ & $4(<1)$ & $0(0)$ & $1(2)$ & 0.06 \\
\hline Ciliary body leiomyoma & $2(<1)$ & $0(0)$ & $2(<1)$ & $0(0)$ & 0.02 \\
\hline Ciliary body PECOma & $1(<1)$ & $0(0)$ & $1(<1)$ & $0(0)$ & 0.15 \\
\hline $\begin{array}{l}\text { Retinal pigment epithelial } \\
\text { adenoma }\end{array}$ & $1(<1)$ & $0(0)$ & $1(<1)$ & $0(0)$ & 0.15 \\
\hline Choroidal osteoma & $1(<1)$ & $0(0)$ & $0(0)$ & $1(2)$ & $<0.001$ \\
\hline
\end{tabular}


Table 2 (continued)

\begin{tabular}{|c|c|c|c|c|c|}
\hline Feature & $\begin{array}{l}\text { All cases } \\
n=2009 \\
n(\%)\end{array}$ & $\begin{array}{l}\text { Young age } \\
(\leq 20 \text { years }) \\
n=1531 n(\%)\end{array}$ & $\begin{array}{l}\text { Middle age (>20 } \\
\text { to } 60 \text { years) } \\
n=418 n(\%)\end{array}$ & $\begin{array}{l}\text { Older age } \\
\text { (>60 years) } \\
n=60 n(\%)\end{array}$ & $p$-value \\
\hline Choroidal schwannoma & $2(<1)$ & $0(0)$ & $2(<1)$ & $0(0)$ & 0.02 \\
\hline Choroidal melanocytoma & $4(<1)$ & $2(<1)$ & $0(0)$ & $2(3)$ & $<0.001$ \\
\hline Choroidal hemangioma & $4(<1)$ & $1(<1)$ & $2(<1)$ & $1(2)$ & 0.009 \\
\hline $\begin{array}{l}\text { Lymphoplasmacytic lesion of } \\
\text { the uvea }\end{array}$ & $1(<1)$ & $0(0)$ & $1(<1)$ & $0(0)$ & 0.15 \\
\hline $\begin{array}{l}\text { Optic nerve sheath } \\
\text { meningioma }\end{array}$ & $1(<1)$ & $0(0)$ & $1(<1)$ & $0(0)$ & 0.15 \\
\hline \multicolumn{6}{|l|}{ Malignant tumor } \\
\hline $\begin{array}{l}\text { Ocular surface squamous } \\
\text { neoplasia }\end{array}$ & $25(1)$ & $3(<1)$ & $12(3)$ & $10(17)$ & $<0.001$ \\
\hline $\begin{array}{l}\text { Conjunctival sarcomatoid } \\
\text { carcinoma }\end{array}$ & $1(<1)$ & $0(0)$ & $1(<1)$ & $0(0)$ & 0.15 \\
\hline Retinoblastoma & $1262(63)$ & $1257(82)$ & $5(1)$ & $0(0)$ & $<0.001$ \\
\hline Uveal melanoma & $172(9)$ & $6(<1)$ & $141(34)$ & $25(42)$ & $<0.001$ \\
\hline Choroidal metastasis & $12(<1)$ & $0(0)$ & $9(2)$ & $3(5)$ & $<0.001$ \\
\hline
\end{tabular}

PECO Perivascular epithelioid cell tumor

$p<0.001)$ were common in the older patients. Overall, based on age at enucleation, retinoblastoma $(n=1257,82 \% ; p<$ $0.001)$ was the most common indication of enucleation in young age, atrophic bulbi or phthisis bulbi $(n=163,39 \%$; $p<0.001)$ in middle-age adults, and uveal melanoma $(n=$ $25,42 \% ; p<0.001$ ) in older adults (Table 2). The details of diagnosis based on the age at enucleation are listed in Table 3.

Of 2009 enucleations included in the study, $9 \%$ were performed from 1996 to 2000, 19\% from 2001 to 2005 , $32 \%$ from 2006 to $2010,27 \%$ from 2011 to 2015 , and $12 \%$ from 2016 to 2018 . The mean age at enucleation gradually decreased over the years (150 months from the years 1996 through 2000, 157 months from 2001 to 2005, 182 months from 2006 to 2010,132 months from 2011 to 2015 , to 135 months from 2016 to 2018; $p<0.001$ ). Over the years, there was a decreasing trend of enucleations for atrophic bulbi/phthisis bulbi/painful blind eye (33\% from the years 1996 through $2000,24 \%$ from 2001 to $2005,19 \%$ from 2006 to $2010,9 \%$ from 2011 to 2015, to $3 \%$ from 2016 to 2018; $p<0.001)$ and acute trauma (3\% from the years 1996 through $2000,7 \%$ from 2001 to $2005,8 \%$ from 2006 to $2010,<1 \%$ from 2011 to 2015 , to $<1 \%$ from 2016 to 2018 ; $p<0.001)$ and an increasing trend for intraocular tumors including retinoblastoma (56\% from the years 1996 through $2000,58 \%$ from 2001 to $2005,55 \%$ from 2006 to 2010 , $71 \%$ from 2011 to 2015 , to $76 \%$ from 2016 to 2018 ; $p=$ 0.01 ) and uveal melanoma (3\% from the years 1996 through $2000,7 \%$ from 2001 to $2005,8 \%$ from 2006 to $2010,11 \%$ from 2011 to 2015 , to $12 \%$ from 2016 to $2018 ; p=0.006$ ) Table 4.

\section{Discussion}

The indications for enucleation have varied over time depending on the time period and the geographic location. Studies from the US have revealed glaucoma (22\%-35\%), acute trauma (48\%), intraocular tumors (21 to $48 \%$ ) and painful blind eye $(63 \%)$ [1, 4-8]. as the most common causes of enucleation. Studies from Europe have revealed blind painful eye ( $37 \%$ to $46 \%$ ), tumors ( $26 \%$ to $34 \%$ ), and trauma $(39 \%)$ as the most common indications for enucleation $[2,3,9,10]$. Studies from Iran and Arab Nations revealed trauma (33\% to 50\%) and malignant tumors (20\%) as the most common indications for enucleation [11-15]. Studies from Nepal have revealed intraocular tumors (72\%) as the most common indication for enucleation [16]. Studies from China have revealed trauma (63\% to $66 \%$ ) as the most common indications for enucleation/evisceration [17, 18]. There are limited studies from India. As per published literature, the most common indications for enucleation in Asian Indians are malignant tumors (49\% to $61 \%)$ and inflammatory/infectious etiology (40\%) [19-21]. In our study, the most common indication for enucleation was malignant tumors accounting for $73 \%$ of cases $(p<0.001)$, with higher proportion in young patients (83\%) and older patients $(63 \%)$. Acute trauma and sequelae of trauma were 
Table 3 Enucleation in Asian Indian population: Diagnosis as per decade of life

\begin{tabular}{|c|c|c|c|c|c|c|c|c|c|}
\hline & \multicolumn{9}{|c|}{ Age at presentation (years) } \\
\hline & $\begin{array}{l}\leq 10 n= \\
1423 n \\
(\%)\end{array}$ & $\begin{array}{l}>10 \text { to } 20 \\
n=108 n \\
(\%)\end{array}$ & $\begin{array}{l}>20 \text { to } 30 \\
n=155 n \\
(\%)\end{array}$ & $\begin{array}{l}>30 \text { to } 40 \\
n=86 n \\
(\%)\end{array}$ & $\begin{array}{l}>40 \text { to } 50 \\
n=111 n \\
(\%)\end{array}$ & $\begin{array}{l}>50 \text { to } 60 \\
n=66 n \\
(\%)\end{array}$ & $\begin{array}{l}>60 \text { to } 70 \\
n=36 n \\
(\%)\end{array}$ & $\begin{array}{l}>70 \text { to } 80 \\
n=17 n \\
(\%)\end{array}$ & $\begin{array}{l}>80 \text { to } 90 \\
n=7 n \\
(\%)\end{array}$ \\
\hline \multicolumn{10}{|l|}{ Gender } \\
\hline Male & $830(58)$ & $57(53)$ & $106(68)$ & $55(64)$ & $67(60)$ & $39(59)$ & $25(69)$ & $10(59)$ & $2(29)$ \\
\hline Female & $593(42)$ & $51(47)$ & $49(32)$ & $31(36)$ & $44(40)$ & $27(41)$ & $11(31)$ & $7(41)$ & $5(71)$ \\
\hline \multicolumn{10}{|l|}{ Enucleation } \\
\hline Primary & $972(68)$ & $102(94)$ & $153(99)$ & $84(98)$ & $108(97)$ & $62(94)$ & $34(94)$ & $15(88)$ & $6(86)$ \\
\hline Secondary & $451(32)$ & $6(6)$ & $2(1)$ & $2(2)$ & $3(3)$ & $4(6)$ & $2(6)$ & $2(2)$ & $1(14)$ \\
\hline \multicolumn{10}{|c|}{ Clinical diagnosis correlating with histopathology diagnosis } \\
\hline Yes & $1376(97)$ & $103(95)$ & $150(97)$ & $83(96)$ & $107(96)$ & $63(95)$ & $33(92)$ & $17(100)$ & $5(71)$ \\
\hline No & $47(3)$ & $5(5)$ & $5(3)$ & $3(4)$ & $4(4)$ & $3(5)$ & $3(8)$ & $0(0)$ & $2(29)$ \\
\hline \multicolumn{10}{|l|}{ Diagnosis } \\
\hline \multicolumn{10}{|l|}{ Congenital anomalies } \\
\hline Clinical anophthalmos & $0(0)$ & $1(<1)$ & $0(0)$ & $0(0)$ & $0(0)$ & $0(0)$ & $0(0)$ & $0(0)$ & $0(0)$ \\
\hline Noorie's disease & $1(<1)$ & $0(0)$ & $0(0)$ & $0(0)$ & $0(0)$ & $0(0)$ & $0(0)$ & $0(0)$ & $0(0)$ \\
\hline $\begin{array}{l}\text { Primary hyperplastic primary } \\
\text { vitreous }\end{array}$ & $2(<1)$ & $0(0)$ & $0(0)$ & $0(0)$ & $0(0)$ & $0(0)$ & $0(0)$ & $0(0)$ & $0(0)$ \\
\hline Retinal dysplasia & $3(<1)$ & $0(0)$ & $0(0)$ & $0(0)$ & $0(0)$ & $0(0)$ & $0(0)$ & $0(0)$ & $0(0)$ \\
\hline \multicolumn{10}{|l|}{ Retinal vascular pathology } \\
\hline Coats disease & $43(3)$ & $6(5)$ & $0(0)$ & $0(0)$ & $0(0)$ & $1(2)$ & $0(0)$ & $0(0)$ & $0(0)$ \\
\hline \multicolumn{10}{|l|}{ Acute Inflammation/infection } \\
\hline $\begin{array}{l}\text { Intraocular cysticercosis/ } \\
\text { toxocariasis/parasitic } \\
\text { granuloma }\end{array}$ & $7(<1)$ & $0(0)$ & $0(0)$ & $0(0)$ & $0(0)$ & $0(0)$ & $0(0)$ & $0(0)$ & $0(0)$ \\
\hline $\begin{array}{l}\text { Endophthalmitis/ } \\
\text { panophthalmitis }\end{array}$ & $9(<1)$ & $0(0)$ & $0(0)$ & $4(5)$ & $2(2)$ & $2(3)$ & $0(0)$ & $2(12)$ & $1(14)$ \\
\hline $\begin{array}{l}\text { Necrotizing granulomatous } \\
\text { uveitis }\end{array}$ & $4(<1)$ & $1(<1)$ & $0(0)$ & $0(0)$ & $0(0)$ & $0(0)$ & $1(3)$ & $0(0)$ & $0(0)$ \\
\hline Acute trauma & $13(<1)$ & $11(10)$ & $32(21)$ & $17(20)$ & $13(12)$ & $6(9)$ & $1(3)$ & $0(0)$ & $0(0)$ \\
\hline \multicolumn{10}{|l|}{ Sequelae of prior trauma or infection } \\
\hline $\begin{array}{l}\text { Phthisis bulbi/atrophic bulbi/ } \\
\text { Painful blind eye }\end{array}$ & $83(6)$ & $74(69)$ & $84(54)$ & $26(32)$ & $35(32)$ & $18(27)$ & $7(19)$ & $3(18)$ & $2(29)$ \\
\hline \multicolumn{10}{|l|}{ Benign tumor } \\
\hline $\begin{array}{c}\text { Ciliary body } \\
\text { medulloepithelioma }\end{array}$ & $3(<1)$ & $1(<1)$ & $0(0)$ & $0(0)$ & $0(0)$ & $0(0)$ & $1(3)$ & $0(0)$ & $0(0)$ \\
\hline Ciliary body leiomyoma & $0(0)$ & $0(0)$ & $0(0)$ & $0(0)$ & $2(2)$ & $0(0)$ & $0(0)$ & $0(0)$ & $0(0)$ \\
\hline Ciliary body PECOma & $0(0)$ & $0(0)$ & $1(<1)$ & $0(0)$ & $0(0)$ & $0(0)$ & $0(0)$ & $0(0)$ & $0(0)$ \\
\hline $\begin{array}{l}\text { Retinal pigment epithelial } \\
\text { adenoma }\end{array}$ & $0(0)$ & $0(0)$ & $0(0)$ & $0(0)$ & $1(<1)$ & $0(0)$ & $0(0)$ & $0(0)$ & $0(0)$ \\
\hline Choroidal osteoma & $0(0)$ & $0(0)$ & $0(0)$ & $0(0)$ & $0(0)$ & $0(0)$ & $0(0)$ & $0(0)$ & $1(14)$ \\
\hline Choroidal schwannoma & $0(0)$ & $0(0)$ & $0(0)$ & $1(1)$ & $0(0)$ & $1(2)$ & $0(0)$ & $0(0)$ & $0(0)$ \\
\hline Choroidal melanocytoma & $1(<1)$ & $1(<1)$ & $0(0)$ & $0(0)$ & $0(0)$ & $0(0)$ & $2(6)$ & $0(0)$ & $0(0)$ \\
\hline Choroidal hemangioma & $1(<1)$ & $0(0)$ & $1(<1)$ & $0(0)$ & $1(<1)$ & $0(0)$ & $1(3)$ & $0(0)$ & $0(0)$ \\
\hline $\begin{array}{l}\text { Lymphoplasmacytic lesion of } \\
\text { the uvea }\end{array}$ & $0(0)$ & $0(0)$ & $1(<1)$ & $0(0)$ & $0(0)$ & $0(0)$ & $0(0)$ & $0(0)$ & $0(0)$ \\
\hline $\begin{array}{l}\text { Optic nerve sheath } \\
\text { meningioma }\end{array}$ & $0(0)$ & $0(0)$ & $0(0)$ & $1(1)$ & $0(0)$ & $0(0)$ & $0(0)$ & $0(0)$ & $0(0)$ \\
\hline
\end{tabular}


Table 3 (continued)

\begin{tabular}{|c|c|c|c|c|c|c|c|c|c|}
\hline & \multicolumn{9}{|c|}{ Age at presentation (years) } \\
\hline & $\begin{array}{l}\leq 10 n= \\
1423 n \\
(\%)\end{array}$ & $\begin{array}{l}>10 \text { to } 20 \\
n=108 n \\
(\%)\end{array}$ & $\begin{array}{l}>20 \text { to } 30 \\
n=155 n \\
(\%)\end{array}$ & $\begin{array}{l}>30 \text { to } 40 \\
n=86 n \\
(\%)\end{array}$ & $\begin{array}{l}>40 \text { to } 50 \\
n=111 n \\
(\%)\end{array}$ & $\begin{array}{l}>50 \text { to } 60 \\
n=66 n \\
(\%)\end{array}$ & $\begin{array}{l}>60 \text { to } 70 \\
n=36 n \\
(\%)\end{array}$ & $\begin{array}{l}>70 \text { to } 80 \\
n=17 n \\
(\%)\end{array}$ & $\begin{array}{l}>80 \text { to } 90 \\
n=7 n \\
(\%)\end{array}$ \\
\hline \multicolumn{10}{|l|}{ Malignant tumor } \\
\hline $\begin{array}{l}\text { Ocular surface squamous } \\
\text { neoplasia }\end{array}$ & $0(0)$ & $3(3)$ & $5(3)$ & $2(2)$ & $3(3)$ & $2(3)$ & $4(11)$ & $5(30)$ & $1(14)$ \\
\hline $\begin{array}{l}\text { Conjunctival sarcomatoid } \\
\text { carcinoma }\end{array}$ & $0(0)$ & $0(0)$ & $1(<1)$ & $0(0)$ & $0(0)$ & $0(0)$ & $0(0)$ & $0(0)$ & $0(0)$ \\
\hline Retinoblastoma & $1252(88)$ & $5(5)$ & $3(2)$ & $0(0)$ & $1(<1)$ & $1(2)$ & $0(0)$ & $0(0)$ & $0(0)$ \\
\hline Uveal melanoma & $1(<1)$ & $5(5)$ & $26(17)$ & $33(38)$ & $48(43)$ & $34(52)$ & $19(53)$ & $5(30)$ & $1(14)$ \\
\hline Choroidal metastasis & $0(0)$ & $0(0)$ & $1(<1)$ & $2(2)$ & $5(5)$ & $1(2)$ & $0(0)$ & $2(12)$ & $1(14)$ \\
\hline
\end{tabular}

PECO Perivascular epithelioid cell tumor

more common in middle-aged adults $(16 \%, p<0.001$ and $39 \%, p<0.001$, respectively) compared to younger patients ( $2 \%$ and $10 \%$, respectively) or older adults ( $2 \%$ and $20 \%$, respectively).

Amongst the malignant tumors, retinoblastoma (63\%) was the most common cause for enucleation in our series. This corresponds to other studies from India, where retinoblastoma was the most common malignant tumor necessitating enucleation [19-21]. However, the rate of enucleations due to retinoblastoma was much higher in our study compared to other studies ( $37 \%$ to $49 \%$ ), and this could be related to referral bias and the time period of the study [19-21]. The higher rate of enucleations for retinoblastoma in India could also be related to advanced disease at presentation compared to the West [22]. In the West, uveal melanoma is the most common malignant intraocular tumor necessitating enucleation $[4,5]$. This difference could be related to the difference in the proportion of retinoblastoma versus uveal melanoma in the West and in India. While the estimated annual incidence of retinoblastoma is 258 in North America, it is over 1500 cases in India [23, 24]; and uveal melanoma is less common in Asia compared to light-eyed, fair-skinned Caucasians, with an estimated annual incidence of 857 cases in Asians versus 4351 in non-Hispanic Caucasians [23]. However, with improved treatment modalities in the West, there is a decreasing trend towards enucleation of the eye for uveal melanoma and retinoblastoma [4].

In our study, the indication for enucleation also varied based on the age group. Amongst the ocular malignant tumors, retinoblastoma $(82 \% ; p<0.001)$ was the most common indication for enucleation in younger patients, and uveal melanoma was the common indication in middle-aged $(34 \% ; p<0.001)$ and older adults $(42 \% ; p<0.001)$. Uveal melanoma is more common after the $6^{\text {th }}$ decade in the West, but in India, it is more commonly seen in the $4^{\text {th }}$ and $5^{\text {th }}$ decade $[25,26]$. Thus the common malignant intraocular tumor in middle-aged adults necessitating enucleation was uveal melanoma in our study. Enucleation for ocular surface squamous neoplasia and choroidal metastases was also more common in older patients compared to young patients and middle-aged adults, and this corresponds to the higher incidence of both these diseases in this age group.

In this study, the most common indication for enucleation in young patients was retinoblastoma (82\%), atrophic bulbi or phthisis bulbi (39\%) in middle-age adults, and uveal melanoma (42\%) in older adults, suggesting ocular tumors in young and older age groups and desire for better cosmesis with a customized ocular prosthesis in middle-age patients. Similar to our study, in a study of 746 pediatric enucleations in the US, retinoblastoma $(n=330,45 \%)$ and trauma $(n=233,32 \%)$ were the most common diagnosis [6], though the enucleation rate was much higher at $82 \%$ for retinoblastoma and was much lower for trauma (acute trauma and sequelae of trauma) at $12 \%$ in our study. Over time, there was a steep decrease in pediatric non-retinoblastoma enucleations and an increase in retinoblastoma enucleations [6]. This is similar to our study where an overall decreasing trend was noted in number of enucleations for acute trauma (3\% during 1996 to 2000 versus < $1 \%$ during 2016 to 2018 ; $p<$ 0.001 ) or sequelae of trauma (33\% during 1996 to 2000 versus 3\% during 2016 to $2018 ; p<0.001$ ) and an increasing trend was noted in enucleations for retinoblastoma (56\% during 1996 to 2000 versus $76 \%$ during 2016 to 2018; $p=0.01$ ). There was also an increased trend of enucleations for uveal melanoma over the years $(3 \%$ during 1996 to 2000 versus $12 \%$ during 2016 to 2018 ; $p=$ 0.006). This is in contrast to studies from the West, where there was a decreasing trend of enucleations for uveal melanoma over the years [3-5]. The trend seen in our study corresponds to improved quality of care and 
Table 4 Enucleation in Asian Indian population: trend over the years

\begin{tabular}{|c|c|c|c|c|c|c|}
\hline Feature & $\begin{array}{l}\text { Years } 1996 \text { to } \\
2000 n=189 \\
(\%)\end{array}$ & $\begin{array}{l}\text { Years } 2001 \text { to } \\
2005 n=383 \\
(\%)\end{array}$ & $\begin{array}{l}\text { Years } 2006 \text { to } \\
2010 n=650 \\
(\%)\end{array}$ & $\begin{array}{l}\text { Years } 2011 \text { to } \\
2015 n=538 \\
(\%)\end{array}$ & $\begin{array}{l}\text { Years } 2016 \text { to } \\
\text { March } 2018 n= \\
249(\%)\end{array}$ & $p$-value \\
\hline $\begin{array}{l}\text { Mean age at presentation (months) } \\
\text { (Median, range) }\end{array}$ & $\begin{array}{l}150(48,2 \text { to } \\
1020)\end{array}$ & $\begin{array}{l}157(48,0.3 \text { to } \\
1008)\end{array}$ & $\begin{array}{l}182(48,1 \text { to } \\
1020)\end{array}$ & $\begin{array}{l}132(36,0.7 \text { to } \\
384)\end{array}$ & $135(36,1$ to 984$)$ & $<0.0001$ \\
\hline \multicolumn{7}{|l|}{ Gender } \\
\hline Male & $116(61)$ & $249(65)$ & $380(58)$ & $300(56)$ & $146(59)$ & 0.71 \\
\hline Female & $73(39)$ & $134(35)$ & $270(42)$ & $238(44)$ & $103(41)$ & 0.45 \\
\hline \multicolumn{7}{|l|}{ Diagnosis } \\
\hline Congenital anomalies & $0(0)$ & $0(0)$ & $0(0)$ & $0(0)$ & $0(0)$ & N/A \\
\hline Clinical anophthalmos & $0(0)$ & $0(0)$ & $0(0)$ & $1(<1)$ & $0(0)$ & 0.60 \\
\hline Noorie's disease & $0(0)$ & $0(0)$ & $0(0)$ & $1(<1)$ & $0(0)$ & 0.60 \\
\hline $\begin{array}{l}\text { Primary hyperplastic primary } \\
\text { vitreous }\end{array}$ & $0(0)$ & $0(0)$ & $2(<1)$ & $0(0)$ & $0(0)$ & 0.38 \\
\hline Retinal dysplasia & $1(<1)$ & $1(<1)$ & $0(0)$ & $1(<1)$ & $0(0)$ & 0.47 \\
\hline \multicolumn{7}{|l|}{ Retinal vascular pathology } \\
\hline Coats disease & $3(2)$ & $6(2)$ & $16(2)$ & $20(4)$ & $5(2)$ & 0.26 \\
\hline \multicolumn{7}{|l|}{ Acute Inflammation/infection } \\
\hline $\begin{array}{l}\text { Intraocular cysticercosis/ } \\
\text { toxocariasis/parasitic granuloma }\end{array}$ & $1(<1)$ & $1(<1)$ & $3(<1)$ & $1(<1)$ & $1(<1)$ & 0.92 \\
\hline Endophthalmitis/panophthalmitis & $0(0)$ & $4(1)$ & $13(2)$ & $3(<1)$ & $0(0)$ & 0.02 \\
\hline $\begin{array}{l}\text { Necrotizing granulomatous } \\
\text { uveitis }\end{array}$ & $1(<1)$ & $0(0)$ & $3(<1)$ & $2(<1)$ & $0(0)$ & 0.58 \\
\hline Acute trauma & $6(3)$ & $26(7)$ & $55(8)$ & $5(<1)$ & $1(<1)$ & $<0.001$ \\
\hline \multicolumn{7}{|c|}{ Sequelae of prior trauma or infection } \\
\hline $\begin{array}{l}\text { Phthisis bulbi/atrophic bulbi/ } \\
\text { Painful blind eye }\end{array}$ & $63(33)$ & $93(24)$ & $121(19)$ & $48(9)$ & $7(3)$ & $<0.001$ \\
\hline \multicolumn{7}{|l|}{ Benign tumor } \\
\hline Ciliary body medulloepithelioma & $0(0)$ & $2(<1)$ & $2(<1)$ & $0(0)$ & $1(<1)$ & 0.51 \\
\hline Ciliary body leiomyoma & $0(0)$ & $0(0)$ & $1(<1)$ & $1(<1)$ & $0(0)$ & 0.84 \\
\hline Ciliary body PECOma & $0(0)$ & $0(0)$ & $1(<1)$ & $0(0)$ & $0(0)$ & 0.72 \\
\hline $\begin{array}{l}\text { Retinal pigment epithelial } \\
\text { adenoma }\end{array}$ & $0(0)$ & $0(0)$ & $1(<1)$ & $0(0)$ & $0(0)$ & 0.72 \\
\hline Choroidal osteoma & $0(0)$ & $0(0)$ & $1(<1)$ & $0(0)$ & $0(0)$ & 0.72 \\
\hline Choroidal schwannoma & $1(<1)$ & $0(0)$ & $0(0)$ & $0(0)$ & $1(<1)$ & 0.12 \\
\hline Choroidal melanocytoma & $0(0)$ & $0(0)$ & $0(0)$ & $1(<1)$ & $3(1)$ & 0.05 \\
\hline Choroidal hemangioma & $0(0)$ & $0(0)$ & $1(<1)$ & $1(<1)$ & $2(<1)$ & 0.22 \\
\hline $\begin{array}{l}\text { Lymphoplasmacytic lesion of the } \\
\text { uvea }\end{array}$ & $1(<1)$ & $0(0)$ & $0(0)$ & $0(0)$ & $0(0)$ & 0.05 \\
\hline Optic nerve sheath meningioma & $0(0)$ & $0(0)$ & $0(0)$ & $1(<1)$ & $0(0)$ & 0.60 \\
\hline \multicolumn{7}{|l|}{ Malignant tumor } \\
\hline $\begin{array}{l}\text { Ocular surface squamous } \\
\text { neoplasia }\end{array}$ & $0(0)$ & $2(<1)$ & $12(2)$ & $6(1)$ & $5(2)$ & 0.14 \\
\hline $\begin{array}{l}\text { Conjunctival sarcomatoid } \\
\text { carcinoma }\end{array}$ & $0(0)$ & $0(0)$ & $0(0)$ & $0(0)$ & $1(<1)$ & 0.13 \\
\hline Retinoblastoma & $105(56)$ & $223(58)$ & $360(55)$ & $384(71)$ & $190(76)$ & 0.01 \\
\hline Uveal melanoma & $6(3)$ & $25(7)$ & $53(8)$ & $57(11)$ & $31(12)$ & 0.006 \\
\hline Choroidal metastasis & $1(<1)$ & $0(0)$ & $9(1)$ & $5(<1)$ & $1(<1)$ & 0.16 \\
\hline
\end{tabular}

PECO Perivascular epithelioid cell tumor 
preference for eviscerations for trauma and its sequelae and increased referral pattern to the institute for retinoblastoma and uveal melanoma over the years. Increasing evidence of low incidence of sympathetic ophthalmia in ocular trauma following eviscerations has also contributed towards the shift of trend towards eviscerations in these cases [27].

The drawbacks of the study include retrospective nature of the study and lack of data related to total number of patients with each disease pattern to exactly determine the proportion of patients undergoing enucleations for a particular ocular pathology, which is beyond the scope of this study. However, this large dataset of 2009 patients over a prolonged 22-year time period allows studying the trend of enucleations over the years in Asian Indians.

In summary, there are still a significant number of patients requiring enucleation for advanced intraocular tumors, especially retinoblastoma and uveal melanoma. Efforts towards early referral, early diagnosis, and appropriate treatment might reverse this trend of enucleation in the future. Acute trauma and sequelae of trauma are more common in middle-aged patients, indicating a need for better eye protection in this age group. Improved quality of care for non-tumor pathologies has decreased the morbidity related to enucleation.

Support provided by the Operation Eyesight Universal Institute for Eye Cancer (SK), and Hyderabad Eye Research Foundation (SK), Hyderabad, India. The funders had no role in the preparation, review or approval of the manuscript. Statistical analysis performed by Dr Ashik Mohamed, MBBS, M.Tech, Ophthalmic Biophysics, L V Prasad Eye Institute, Hyderabad, India.

\section{Summary}

\section{What was known before}

- The traditional orbital wall reconstruction of blowout fracture is to visually inspect the fracture site and use eye measurements to cut a two-dimensional orbital implant that corresponds to the anatomical structure of the fracture site.

- The implants that do not fit the anatomical structure of a fracture site well can cause complications such as enophthalmos, diplopia and displacement of the implant.

\section{What this study adds}

- We introduced the surgical technique of orbital wall reconstruction using 3D-printed customized orbital implant templates with low cost and quantitatively demonstrated optimal reconstruction of anatomic contours.

\section{Compliance with ethical standards}

Conflict of interest The authors declare that they have no conflict of interest.

\section{References}

1. Erie JC, Nevitt MP, Hodge D, Ballard DJ. Incidence of enucleation in a defined population. Am J Ophthalmol. 1992;113:138-44.

2. Sigurdsson H, Thórisdóttir S, Björnsson JK. Enucleation and evisceration in Iceland 1964-1992. Study in a defined population. Acta Ophthalmol Scand. 1998;76:103-7.

3. Geirsdottir A, Agnarsson BA, Helgadottir G, Sigurdsson H. Enucleation in Iceland 1992-2004: study in a defined population. Acta Ophthalmol. 2014;92:121-5.

4. Setlur VJ, Parikh JG, Rao NA. Changing causes of enucleation over the past 60 years. Graefes Arch Clin Exp Ophthalmol. 2010;248:593-7.

5. Kitzmann AS, Weaver AL, Lohse CM, Buettner H, Salomão DR. Clinicopathologic correlations in 646 consecutive surgical eye specimens, 1990-2000. Am J Clin Pathol. 2003;119:594-601.

6. Huang S, Crawford JB, Porco T, Rutar T. Clinicopathologic review of pediatric enucleations during the last 50 years. $\mathrm{J}$ AAPOS. 2010;14:328-33.

7. de Gottrau P, Holbach LM, Naumann GO. Clinicopathological review of 1146 enucleations (1980-90). Br J Ophthalmol. 1994;78:260-5.

8. Yousuf SJ, Jones LS, Kidwell ED Jr. Enucleation and evisceration: 20 years of experience. Orbit. 2012;31:211-5.

9. Rasmussen ML, Prause JU, Johnson M, Kamper-Jørgensen F, Toft PB. Review of 345 eye amputations carried out in the period 1996-2003, at Rigshospitalet, Denmark. Acta Ophthalmol. 2010;88:218-21.

10. Hansen AB, Petersen C, Heegaard S, Prause JU. Review of 1028 bulbar eviscerations and enucleations. Changes in aetiology and frequency over a 20-year period. Acta Ophthalmol Scand. 1999;77:331-5.

11. Farokhfar A, Ahmadzadeh-Amiri A, Sheikhrezaee MR, Gorji MAH, Agaei N. Common causes of eye enucleation among patients. J Nat Sci Biol Med. 2017;8:150-153.

12. Ababneh $\mathrm{OH}$, AboTaleb EA, Abu Ameerh MA, Yousef YA. Enucleation and evisceration at a tertiary care hospital in a developing country. BMC Ophthalmol. 2015;15:120.

13. Kord Valeshabad A, Naseripour M, Asghari R, et al. Enucleation and evisceration: indications, complications and clinicopathological correlations. Int J Ophthalmol. 2014;7:677-80.

14. Al-Dahmash SA, Bakry SS, Almadhi NH, Alashgar LM. Indications for enucleation and evisceration in a tertiary eye hospital in Riyadh over a 10-year period. Ann Saudi Med. 2017;37: 313-316.

15. Koylu MT, Gokce G, Uysal Y, Ceylan OM, Akıncıoglu D, Gunal A. Indications for eye removal surgeries. A 15-year experience at a tertiary military hospital. Saudi Med J. 2015;36:1205-9.

16. Lavaju P, Badhu BP, Shah S, Upadhyaya P. Indications for destructive eye surgeries at tertiary care hospital, eastern Nepal: a five years experience. Health Renaiss. 2015;13:161-168.

17. Zhang Y, Zhang MN, Wang X, Chen XF. Removal of the eye in a tertiary care center of China: a retrospective study on 573 cases in 20 years. Int J Ophthalmol. 2015;8:1024-30.

18. Cheng GY, Li B, Li LQ, et al. Review of 1375 enucleations in the TongRen Eye Centre. Beijing Eye (Lond). 2008;22:1404-9.

19. Vemuganti GK, Jalali S, Honavar SG, Shekar GC. Enucleation in a tertiary eye care centre in India: prevalence, current indications 
and clinicopathological correlation. Eye (Lond). 2001;15(Pt 6):760-5.

20. Sengupta S, Krishnakumar S, Biswas J, Gopal L, Khetan V. Fifteen-year trends in indications for enucleation from a tertiary care center in South India. Indian J Ophthalmol. 2012;60:179-82.

21. Bal A, Mohan H, Chabbra S, Sood S. Causes of enucleation in Northern India (1995-2005). Eur J Ophthalmol. 2007;17:638-41.

22. Kaliki S, Patel A, Iram S, Ramappa G, Mohamed A, Palkonda VAR Retinoblastoma in India: Clinical Presentation and Outcome in 1457 Patients (2074 Eyes). Retina 2017. [Epub ahead of print].

23. Kivelä T. The epidemiological challenge of the most frequent eye cancer: retinoblastoma, an issue of birth and death. Br J Ophthalmol. 2009;93:1129-31.
24. Usmanov RH, Kivelä T. Predicted trends in the incidence of retinoblastoma in the Asia-Pacific Region.. Asia Pac J Ophthalmol (Phila). 2014;3:151-7.

25. Dhupper M, Biswas J, Gopal L, Kumar SK, Khetan V. Clinicopathological correlation of choroidal melanoma in Indian population: A study of 113 cases. Oman J Ophthalmol. 2012;5:42-5.

26. Kaliki S, Shields CL. Uveal melanoma: relatively rare but deadly cancer. Eye (Lond). 2017;31:241-257.

27. Zheng $\mathrm{C}, \mathrm{Wu} \mathrm{AY}$. Enucleation versus evisceration in ocular trauma: a retrospective review and study of current literature. Orbit. 2013;32:356-61. 